\title{
The fluoride contents of commercially-available soya milks in the UK
}

\author{
H. Lal, ${ }^{* 1}$ F. V. Zohoori, ${ }^{2}$ N. Omid, ${ }^{1}$ R. Valentine ${ }^{1,3}$ and A. Maguire ${ }^{1}$
}
IN BRIEF
- Provides information on the fluoride content of soya milks, highlighting the wide range of fluoride concentrations seen in soya milks in the UK market.
- Stresses the need for dental professionals to evaluate their child patients' daily fluoride intake when prescribing appropriate preventive therapies.
- Concludes that soya milks do not pose an increased risk for the development of dental fluorosis.

\begin{abstract}
Background In some parts of the world, soya milks are found to be a significant source of fluoride (F). Among western commercial markets, although there has been a sustained increase in soya milk products available for purchase, there are limited data on their $\mathrm{F}$ content. Objective To determine the F content of soya milk products available in the UK market including fresh and ultra-high temperature products in addition to sweetened and unsweetened soya milks. Materials and methods Fifty-two traditional and UK-produced soya milk samples commercially available in northeast England were analysed to determine their $\mathrm{F}$ concentration using a modified hexamethyldisiloxane-facilitated diffusion method with a F-ion-selective electrode coupled to a potentiometer. Results The median F concentration of all products was $0.293 \mu \mathrm{g} / \mathrm{ml}$ ranging from $0.015 \mu \mathrm{g} / \mathrm{ml}$ to $0.964 \mu \mathrm{g} / \mathrm{ml}$. The median F concentration of ultra-high temperature (UHT) $(n=42)$ milks was $0.272 \mu \mathrm{g} / \mathrm{ml}$ lower than $0.321 \mu \mathrm{g} / \mathrm{ml}$ obtained for fresh $(n=10)$ soya milks. Organic soya milks contained less $F$ compared with non-organic for sweetened and unsweetened categories. Conclusion Commercially available soya milks in the UK do not pose an increased risk for dental fluorosis development. Further research is necessary into the manufacturing process of soya milks, which may influence the overall F content of the end product.
\end{abstract}

\section{INTRODUCTION}

The soya bean plant (Glycine max Merrill), originating from China, is a popular and important crop in many countries and particularly the Far East. Soya beans belong to the Leguminosae species, ${ }^{1}$ and are recognised largely due to their high quality protein content in comparison to other legumes, but also due to their beneficial health implications. ${ }^{2}$ They have numerous uses including the manufacture of the soya milk beverage, an aqueous extract of whole soya bean, which is used in preparation of other soya foods such as tofu skin and tofu. ${ }^{3}$ Depending on the growth conditions and variety, the composition of soya beans vary and this consequently affects the composition of the extract; chemical pollutants can also produce a change in the chemical composition of soya beans. ${ }^{4}$ Due to improvements in flavour and taste with the addition of gum and flavourings, ${ }^{5}$ soya milk

${ }^{1}$ Centre for Oral Health Research, School of Dental Sciences, Newcastle University, Newcastle upon Tyne; ${ }^{2}$ School of Health and Social Care, Teesside University, Middlesbrough; ${ }^{3}$ Human Nutrition Research Centre, Newcastle University, Newcastle upon Tyne

${ }^{*}$ Correspondence to: Hari Lal

Email: hari.lal@ncl.ac.uk; Tel: +44 (0)19 12228197

Online article number E8

Refereed Paper - accepted 20 May 2014

DOI: 10.1038/sj.bdj.21014.736

${ }^{\circ}$ British Dental Journal 2014; 217 : E8 remains a popular alternative to bovine milk and the volumes of soya milk produced in the UK has steadily increased from 76.2 to 82.5 (million litres) from January 2010 to January 2014. ${ }^{6}$ This mirrors the increase seen in the production and popularity of soya milk globally. In a recent report ${ }^{7}$ from the United States, soya milk continues to be the most popular non-dairy milk with 11\% of adults drinking soya-based beverages.

The use of soya-based products has some advantages as well as disadvantages. They are positively noted for their health properties, being low in saturated fat and containing no lactose, as well as for their hypocholesterolemic effect. ${ }^{8}$ With the increase in demand for bovine milk substitutes for various reasons, including lactose intolerance $^{9}$ and a desire for vegetarian alternatives, soya milks have provided an alternative. The prevalence of an allergy to cows' milk is estimated to be up to $7 \%$ in infants ${ }^{10}$ and $0.8 \%$ in European adults. ${ }^{11}$ In addition to the nutritional value of the soya bean, the possible protective effects of soya against chronic diseases have been demonstrated in preventing heart disease, ${ }^{12}$ osteoporosis, ${ }^{13}$ particular cancers ${ }^{14}$ and regulating blood pressure. ${ }^{15}$ Moreover, dietary soya can relieve the symptoms of menopausal hot flushes. ${ }^{16}$ There are, however, potential drawbacks with the use of soya products. The soya bean itself is known for its 'beany' flavour, prolonged cooking time and disagreeable taste. It is also rich in phytate, ${ }^{17}$ which has been shown to have an inhibitory effect on iron, zinc, magnesium and calcium absorption. ${ }^{18}$ There is also growing evidence of an increase in the prevalence of food allergies to foods such as soya. ${ }^{19}$ The immune response develops from an IgE-mediated hypersensitivity reaction to the soya protein although, like cows' milk allergy, ${ }^{10}$ the majority of individuals affected outgrow the allergy, which tends to present during childhood..$^{20}$

Soya products have various additional consequences in the oral environment. Soya-based milk and formulas have the ability to lower plaque $\mathrm{pH}$ and can produce a drop in plaque $\mathrm{pH}$ to below the critical $\mathrm{pH}$ for enamel of 5.7. ${ }^{21-23}$ Soya milk has a lower buffering capacity than bovine milk with the rate of acid production by mutans streptococci found to be significantly higher than its comparator at different $\mathrm{pH}$ levels, ${ }^{24}$ resulting in a group of beverages with a higher acidogenic and cariogenic potential. Conversely, limited studies have shown that the fluoride $(F)$ concentration of soyabased products is higher than bovine-based products. ${ }^{25-28}$ Fluorides (F) have been shown to have a beneficial impact on the prevention and decline of dental caries universally. ${ }^{29-31}$ 
However, the excessive ingestion of $\mathrm{F}$ during tooth development can result in structural changes in enamel, which may lead to dental fluorosis. ${ }^{32}$ If this occurs, the enamel is hypomineralised, porous and appears as opaque spots or brown and yellow stains. The severity of the condition depends on factors including the dose, duration and timing of $\mathrm{F}_{\text {intake. }}{ }^{32,33}$ If products containing a high $\mathrm{F}$ content are consistently consumed at critical times of tooth development, this increases the risk of dental fluorosis. As $\mathrm{F}$ is present in common food and drinks readily available on the market, it is important that the $\mathrm{F}$ content of commercially consumed food and drink products is determined and these data disseminated to enable a better understanding of their potential oral health impact.

Among western commercial markets, although there has been a sustained increase in production and number of soya milk products available for purchase, there are limited data on their F content. If soya milk products, readily available in UK markets, are a significant source of $\mathrm{F}$, then it is important for health professionals and public to be aware of this, to help inform monitoring of $\mathrm{F}$ exposure and the provision of appropriate advice regarding their use, especially in children. Thus, the aim of this study was to determine the $\mathrm{F}$ content of soya milk products readily available in the UK market including fresh and ultra-high temperature (UHT) products in addition to sweetened and unsweetened soya milks.

\section{MATERIALS AND METHODS}

\section{Preparation of samples}

A full selection of traditional and UK produced soya milks $(n=52)$ commercially available in northeast England was purchased from nine major supermarkets, grocery stores, traditional Chinese and health food shops in August 2013. One batch number for each sample of ten fresh soya milks was purchased; five sweetened and five unsweetened, along with 42 UHT soya milks; 23 sweetened and 19 unsweetened. The batch number, place of manufacture, ingredients and expiry date for each sample milk were recorded. Fresh soya milks were stored in the refrigerator at $4{ }^{\circ} \mathrm{C}$ while the UHT soya milk was stored at room temperature $\left(20^{\circ} \mathrm{C}\right)$.

Following manufacturers' instructions, before opening, each sample was mixed thoroughly by gentle shaking. Each sample was then distributed into three aliquots, each containing $10 \mathrm{ml}$ of soya milk. Two aliquots were stored at $-20{ }^{\circ} \mathrm{C}$ as a reserve while a third aliquot was stored in the refrigerator overnight at $4{ }^{\circ} \mathrm{C}$ and used to measure the $\mathrm{F}$ concentration of the sample the following day.

\section{Analysis of samples}

Each sample ( $\mathrm{n}=52$ ) was analysed in triplicate (total number of individual samples measured $=156$ ). Measurements of F concentration were made in micrograms/ $\mathrm{ml}(\mu \mathrm{g} / \mathrm{ml})$ which is equivalent to parts per million (ppm). The analysis for $F$ concentration was undertaken using a modified hexamethyldisiloxane (HMDS)facilitated diffusion method with a F-ionselective electrode (Model 9,609: Orion Research) coupled to a potentiometer (Model 720A). ${ }^{34}$ To allow a full recovery of ionic and ionisable $\mathrm{F}$, this technique involves acid diffusion in the presence of hexamethyldisiloxane (HMDS). F standards, ranging from 0.01 to $10 \mathrm{ppm}$ $F$ were used to calibrate the measurement of $\mathrm{F}$ concentration in the samples. The reliability of the $\mathrm{F}$ analytical method was examined by re-analysing 10\% $(n=6)$ of the samples. The validity of method was checked by adding a known amount of $F$ $(0.5 \mu \mathrm{g} / \mathrm{ml})$ to $10 \%(\mathrm{n}=6)$ of samples and determining $\mathrm{F}$ recovery from these samples. Descriptive analysis using Microsoft Excel was undertaken to report the mean, median and range of $\mathrm{F}$ concentration for all samples.

\section{RESULTS}

Figure 1 shows the distribution of $\mathrm{F}$ concentration for all 52 soya milk samples analysed in this study; 52\% ( $n=27)$ had a concentration $<0.3 \mu \mathrm{g} / \mathrm{ml} \quad(<0.3 \mathrm{ppm}$ $\mathrm{F})$, and $8 \%$ of samples $(\mathrm{n}=4)$ had a $\mathrm{F}$ concentration $>0.7 \mu \mathrm{g} / \mathrm{ml}(>0.7 \mathrm{ppm}$ F). The median F concentration of all soya milks was $0.293 \mu \mathrm{g} / \mathrm{ml}$ with a range from $0.015 \mu \mathrm{g} / \mathrm{ml}$ to $0.964 \mu \mathrm{g} / \mathrm{ml}$.

The mean percentage recovery of a known concentration of $\mathrm{F}$ added to the $10 \%$ of randomly selected soya milk samples $(n=6)$ was $96.1 \%$ with a range from $91.5 \%$ to $100.1 \%$ indicating good validity for the method of analysis used. Re-analysis of $10 \%$ of randomly selected samples $(n=6)$ was calculated to be within $0.047 \mu \mathrm{g} / \mathrm{ml}$ with a mean difference (range) of $0.024(0.006-0.047) \mu \mathrm{g} / \mathrm{ml}$ thus showing acceptable reliability for the results.

The mean (SD) and median (range) F concentrations of the UHT and fresh soya milks according to sugars content (that is, sweetened or unsweetened) are presented in Table 1 . The median (range) $\mathrm{F}$ concentration of UHT $(n=42)$ milks was $0.272(0.015-0.964) \mu \mathrm{g} / \mathrm{ml}$, which was lower than the $0.321(0.261-0.444) \mu \mathrm{g} / \mathrm{ml}$ obtained for fresh $(n=10)$ soya milks. The median (range) F content of the sweetened UHT soya milks $(\mathrm{n}=23)$ was $0.300(0.015-0.964) \mu \mathrm{g} /$ $\mathrm{ml}$ compared with the unsweetened drinks ( $n=19)$, which was $0.263(0.040-0.949) \mu \mathrm{g} /$

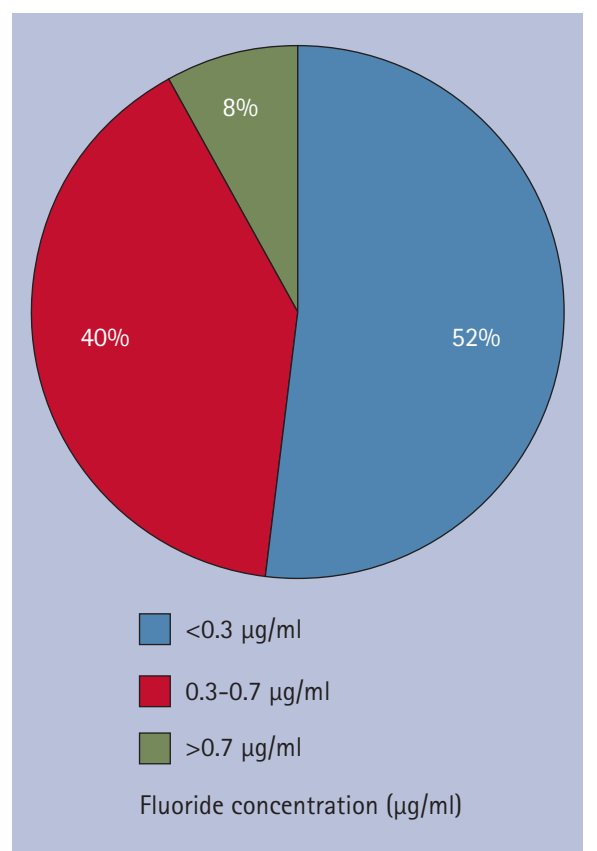

Fig. 1 Proportional distribution of $\mathrm{F}$ concentration $(\mu \mathrm{g} / \mathrm{ml}$ or $\mathrm{ppm})$ for all 52 soya milk samples

ml. For the fresh sweetened soya milks $(n=5)$, the median $\mathrm{F}$ concentration was $0.326 \mu \mathrm{g} / \mathrm{ml}$ and for unsweetened fresh milks ( $\mathrm{n}=5$ ) $0.316 \mu \mathrm{g} / \mathrm{ml}$. For all 28 sweetened soya milk products, the median (range) $\mathrm{F}$ concentration was $0.304(0.015-0.964) \mu \mathrm{g} /$ $\mathrm{ml}$ compared with $0.273(0.040-0.949) \mu \mathrm{g} /$ $\mathrm{ml}$ for the 24 unsweetened products. The median (range) F concentration of nonorganic soya milks was higher for both sweetened $(0.308$ [0.015-0.964] $\mu \mathrm{g} / \mathrm{ml})$ and unsweetened (0.263 [0.066-0.949] $\mathrm{kg} /$ $\mathrm{ml}$ ) products in comparison to organic products $(0.251$ [0.038-0.394] $\mu \mathrm{g} / \mathrm{ml}$ and $0.250(0.040-0.810) \mu \mathrm{g} / \mathrm{ml}$ respectively). All 12 samples marketed as organic products were found to be UHT; four sweetened and eight unsweetened soya milk products.

Table 2 shows the origin, concentration of soya beans (\%) in the soya milk products and their F concentration $(\mu \mathrm{g} / \mathrm{ml})$ based on manufacturer (or brand). The four soya milk products from Asda had the highest soya bean concentration (12\%) but conversely, one of the lowest median $\mathrm{F}$ concentrations $(0.065 \mu \mathrm{g} / \mathrm{ml})$. Alpro produced the highest number of soya milk products for any manufacturer, and used one of the lowest soya bean concentrations of $4.0-6.5 \%$, but these products had the highest median $\mathrm{F}$ concentration $(0.603 \mu \mathrm{g} / \mathrm{ml})$. Product labels identified the country of manufacture of the milks as either the UK, EU, Spain, Hong Kong, Malaysia or Korea. The majority $(90 \%)$ of soya milk products purchased were produced within the EU, while $22 \%$ of sweetened UHT soya milks $(n=5)$ were manufactured outside the EU. The soya milk 
Table 1 Mean (SD) and median (range) F concentration ( $\mu \mathrm{g} / \mathrm{ml}$ or $\mathrm{ppm}$ ) of 52 soya milk products according to milk category and sugars content

\begin{tabular}{|c|c|c|c|}
\hline \multirow{2}{*}{ Category } & \multirow{2}{*}{ No. of samples } & \multicolumn{2}{|c|}{ Fluoride concentration $(\mu \mathrm{g} / \mathrm{ml}$ or $\mathrm{ppm})$} \\
\hline & & Mean (SD) & Median (range) \\
\hline \multicolumn{4}{|l|}{ UHT soya milk } \\
\hline Unsweetened $(n=19)$ & & $0.319(0.241)$ & $0.263(0.040-0.949)$ \\
\hline Non organic & 11 & $0.309(0.251)$ & $0.263(0.066-0.949)$ \\
\hline Organic & 8 & $0.332(0.245)$ & $0.250(0.040-0.810)$ \\
\hline Sweetened $(n=23)$ & & $0.334(0.208)$ & $0.300(0.015-0.964)$ \\
\hline Non organic & 19 & $0.355(0.215)$ & $0.308(0.015-0.964)$ \\
\hline Organic & 4 & $0.233(0.147)$ & $0.251(0.038-0.394)$ \\
\hline All UHT & 42 & $0.327(0.221)$ & $0.272(0.015-0.964)$ \\
\hline \multicolumn{4}{|l|}{ Fresh soya milk* } \\
\hline Unsweetened & 5 & $0.345(0.056)$ & $0.316(0.313-0.444)$ \\
\hline Sweetened & 5 & $0.312(0.048)$ & $0.326(0.261-0.363)$ \\
\hline All Fresh & 10 & $0.328(0.052)$ & $0.321(0.261-0.444)$ \\
\hline All soya milks & 52 & $0.327(0.200)$ & $0.293(0.015-0.964)$ \\
\hline
\end{tabular}

Table 2 Origin, soya bean concentration (\%) and median (range) F concentration ( $\mu \mathrm{g} / \mathrm{ml}$ or $\mathbf{p p m}$ ) of $\mathbf{5 2}$ soya milks according to manufacturer (or brand)

\begin{tabular}{|c|c|c|c|c|}
\hline $\begin{array}{l}\text { Manufacturer } \\
\text { (or brand) }\end{array}$ & $\begin{array}{l}\text { No. of } \\
\text { samples }\end{array}$ & $\begin{array}{l}\text { Origin }{ }^{1} \\
\text { (production site) }\end{array}$ & $\begin{array}{l}\text { Labelled soya bean } \\
\text { concentration range (\%) }\end{array}$ & $\begin{array}{l}\text { Median (range) F } \\
\text { concentration } \\
(\mu \mathrm{g} / \mathrm{ml} \text { or } \mathrm{ppm})\end{array}$ \\
\hline Asda & 4 & EU & 12.0 & $0.065(0.038-0.148)$ \\
\hline Alpro & 8 & EU & $4.0-6.5$ & $0.603(0.313-0.964)$ \\
\hline Calsoy & 1 & Korea & Unavailable & 0.015 \\
\hline Cooperative & 2 & UK & 6.0 & $0.250(0.236-0.264)$ \\
\hline Holland and Barrett & 2 & EU & $6.7-7.2$ & $0.231(0.229-0.232)$ \\
\hline Marks and Spencer & 1 & UK & 11.0 & 0.261 \\
\hline Morrison & 6 & EU & $4.0-6.6$ & $0.322(0.247-0.516)$ \\
\hline Provamel & 4 & EU & $6.4-7.2$ & $0.327(0.212-0.586)$ \\
\hline Sainsbury & 6 & UK & $4.0-7.0$ & $0.274(0.184-0.348)$ \\
\hline Soya Soleil & 1 & EU & 5.5 & 0.066 \\
\hline Tesco & 7 & UK & $4.0-6.0$ & $0.279(0.237-0.314)$ \\
\hline Vitasoy & 3 & Hong Kong & Unavailable & $0.376(0.357-0.427)$ \\
\hline Vivesoy & 3 & Spain & $9.0-13.0$ & $0.391(0.308-0.409)$ \\
\hline Waitrose & 3 & UK & $6.0-6.6$ & $0.224(0.071-0.523)$ \\
\hline Yeo & 1 & Malaysia & 8.0 & 0.381 \\
\hline All products & 52 & $N / A$ & $4.0-13.0$ & $0.293(0.015-0.964)$ \\
\hline
\end{tabular}

Calsoy, manufactured in Korea, did not identify the soya bean concentration and had the lowest F concentration $(0.015 \mu \mathrm{g} /$ $\mathrm{ml}$ ) of all sampled products. The mean $\mathrm{F}$ concentration of the EU, Spain, Hong Kong and Malaysia-produced soya milks had similar median F concentrations of $0.328 \mu \mathrm{g} /$ $\mathrm{ml}(\mathrm{n}=44), 0.369 \mu \mathrm{g} / \mathrm{ml}(\mathrm{n}=3), 0.386 \mu \mathrm{g} / \mathrm{ml}$ $(\mathrm{n}=3)$ and $0.381 \mu \mathrm{g} / \mathrm{ml}(\mathrm{n}=1)$ respectively.

In terms of listing of contents, the inclusiveness of the labelling of sweetened soya milk products varied and not all of the products purchased specified which type of sugars they contained. Of the sweetened products, all fresh milks $(n=5)$ and 6 UHT milks did not identify the sugars they contained, 12 UHT milks included sugars from apple extract, 3 UHT products contained fructose, 1 was identified containing sucrose and 1 UHT contained high fructose corn syrup (fructose and glucose).

\section{DISCUSSION}

This is the first study to solely report the F content of UK soya milk products. A full and comprehensive selection of 52 traditional and UK produced soya milk products representing the majority of commonly used products currently available in the UK were analysed for their F concentration.

The indirect $\mathrm{F}$ analysis method used to determine the $\mathrm{F}$ concentration of the soya milks was developed previously as a gold standard method for $\mathrm{F}$ analysis of biological and non-biological samples. ${ }^{34}$ The results for mean $\mathrm{F}$ recovery and re-analysis of samples indicated strong validity and reliability of the analytical method.

The F concentration of soya milks analysed showed a wide variation from 0.015 to $0.964 \mu \mathrm{g} / \mathrm{ml}$. This range is considerably broader compared with previous studies where a range between 0.253-0.702 $\mu \mathrm{g} /$ $\mathrm{ml}^{35}$ and $0.09-0.29 \mu \mathrm{g} / \mathrm{ml}^{36}$ was reported by two individual groups of Brazilian researchers. However, this broader range of values may be due to the larger sample size in the current study $(n=52)$ compared with three and eight milks respectively analysed in the Brazil studies. Organic soya milks were generally found to contain less F compared with non-organic for both sweetened and unsweetened categories. The conditions of growth of soya beans may have influenced this result. Phosphatic fertilisers ${ }^{37}$ and pesticides often contain $\mathrm{F}$, which may account for the additional $\mathrm{F}$ content in non-organic soya milks, as it may be possible for F, along with other chemicals, ${ }^{38}$ to be taken up by the soya bean plant. $\mathrm{F}$ is also more likely to be absorbed via the root of the plant in low $\mathrm{pH}$ or high soil $\mathrm{F}$ concentrations. ${ }^{37}$ All the organic soya milks in the current study were identified as products of the EU and this may be an additional contributing factor as the site and place of manufacture would influence the chemical composition of the soya bean ${ }^{4}$ and $\mathrm{F}$ content of the water being used to produce the organic soya milk and therefore its $\mathrm{F}$ concentration. The F concentrations of bovine milk have been found to be relatively low, ${ }^{28,39,40}$ with ranges from $0.007-0.068 \mu \mathrm{g} /$ $\mathrm{ml}^{28}$ and $0.007-0.086 \mu \mathrm{g} / \mathrm{ml}^{40}$ where samples of 42 and 68 respectively have been tested, therefore most of the soya milks analysed in this study have a higher F concentration than bovine milks. Moreover, previous studies have indicated the F concentration of soya-based infant formula milks to be higher than other infant formula milks. ${ }^{25-27}$

There was no substantial difference in $\mathrm{F}$ concentrations between the milk categories; UHT sweetened, UHT unsweetened, fresh sweetened and fresh unsweetened soya milks. It was also evident that within the same manufacturer the $\mathrm{F}$ concentration for the majority of products was similar, irrespective of milk category. For example, samples of Tesco's UHT sweetened, UHT sweetened organic, UHT unsweetened, UHT unsweetened organic, fresh sweetened and fresh unsweetened soya milks had mean F concentrations of $0.300 \mu \mathrm{g} / \mathrm{ml}, 0.237 \mu \mathrm{g} /$ $\mathrm{ml}, 0.286 \mu \mathrm{g} / \mathrm{ml}, 0.263 \mu \mathrm{g} / \mathrm{ml}, 0.261 \mu \mathrm{g} /$ $\mathrm{ml}$ and $0.314 \mu \mathrm{g} / \mathrm{ml}$ respectively. The milks containing the highest $\mathrm{F}$ concentrations were all products of the same brand (Alpro). The 
similarity in F concentration would appear to be related to the manufacturing process whereby soya milk is produced by soaking dry soya beans followed by wet grinding of the rehydrated beans. The processing water used for products from the same manufacturer is likely to have the same $\mathrm{F}$ concentration resulting in end products with similar F concentrations. Additionally, some of the samples containing lower $\mathrm{F}$ concentrations contained phytate, an ingredient shown to reduce the absorption of iron, zinc, magnesium and calcium..$^{18}$ It is unclear whether phytate has the same effect on F; the connection has not yet been investigated and further research in this area would be useful.

The labelling of soya milk products was variable; not all of the soya milks purchased had their F content labelled and percentage sugars listings completed. Health professionals and consumers need to be aware of the F content of soya milks to facilitate monitoring of $\mathrm{F}$ exposure, especially in their child patients. In addition, in view of the practice of adding sugars to some of these 'milks' it is important that this information is clearly displayed to enable consumers to make informed purchasing decisions with regard to general and oral health. With the increase in demand for, and consumption of, soya milks for various health and lifestyle reasons, this need for information will increase. All the soya milks sampled in this study contained $\mathrm{F}$ concentrations similar to the recommended $\mathrm{F}$ concentration in community drinking water, ${ }^{41}$ therefore soya milks do not pose an increased risk for the development of dental fluorosis. However, there are potential dental implications with regard to children drinking large volumes of soya milk containing the high $\mathrm{F}$ concentrations and health professionals need to be aware of a child's F intake when prescribing appropriate preventative therapies. Soya-based milks may replace bovine milks in children diagnosed as lactose intolerant and $\mathrm{F}$ intake may be potentially excessive if the $\mathrm{F}$ concentration of the milk is high and F supplements have also been provided. The sugars contents of soya milks may also increase the risk of dental caries in high consumers. More information on the $\mathrm{F}$ and sugars content of soya milks disseminated to and from dental professionals as well as from manufacturers is key to informed decision-making regarding dietary choice and oral health.

In view of the wide variation in $\mathrm{F}$ content of soya milks, further research into the processes of manufacture of soya products is necessary, which may influence the overall $\mathrm{F}$ content of the end product. Moreover, there is a need to review health policies on the recommendation of some soya milks that contain added sugars as an alternative to cow's milk in young children.

The present study was supported by a grant from the Borrow Foundation. The views expressed in this paper are those of the authors and not those of the funding body. The authors report no conflicts of interest.

1. Messina M J. Legumes and soybeans: overview of their nutritional profiles and health effects. Am J Clin Nutr 1999; 70(Suppl 3): 439S-450S.

2. Messina M. Modern applications for an ancient bean: soybeans and the prevention and treatment of chronic disease. J Nutr 1995; 125(Suppl 3): 567S-569S.

3. Lui K. Non-fermented oriental soyfood. In Soybeans: chemistry, technology, and utilization. Gaithersburg: Aspen Publishers, 1997.

4. Patel D K, Kumar R, Prasad S. Variation in the chemical constituents of soybean due to industrial pollution. J Serb Chem Soc 2004; 69: 635-640.

5. Wang B, Xiong Y L, Wang C. Physicochemical and sensory characteristics of flavoured soymilk during refrigeration storage. J Food Quality 2001; 24: 513-526.

6. Kantar Worldpanel. Great Britain liquid milk market. Kantar Worldpanel, 2014. Online information available at http://www.dairyco.org. uk/resources-library/market-information/dairysales-consumption/kantar-worldpanel-liquid-milkmarket/\#.Uwc_CNJhjuM (accessed June 2014).

7. Packaged Facts. Dairy alternative beverages in the US: soy milk, almond milk, rice milk and other dairy milk alternatives. Packaged Facts, 2012 Online information available at https://www.packagedfacts. com/Soy-Milk-Dairy-6504961/ (accessed June 2014).

8. Bakhit R M, Klein B P, Essex-Sorlie D et al. Intake of $25 \mathrm{~g}$ of soybean protein with or without soybean fibre alters plasma lipids in men with elevated cholesterol concentrations. J Nutr 1994; 124: 213-222.

9. Pourpak Z, Farhoudi A, Mahmoudi M et al. The role of cow milk allergy in increasing the severity of atopic dermatitis. Immunol Invest 2004; 33: 69-79.

10. Ludman S, Shah N, Fox A T. Managing cows' milk allergy in children. BMJ 2013; 347: f5424.

11. Burney B G, Potts J, Kummeling I et al. The prevalence and distribution of food sensitization in European adults. Allergy 2014; 69: 365-371.

12. Messina M, Lane B. Soy protein, soybean isoflavones and coronary heart disease risk: where do we stand? Future Lipido/ 2007: 2: 55-74.

13. Putnam S E, Scutt A M, Bicknell K, Priestley C M, Williamson $E$ M. Natural products as alternative treatments for metabolic bone disorders and for maintenance of bone health. Phytother Res 2007 21: 99-112.

14. Andres S, Abraham K, Appel K E, Lampen A. Risks and benefits of dietary isoflavones for cancer. Crit Rev Toxicol 2011; 41: 463-506

15. Kinoshita E, Yamakoshi J, Kikuchi M. Purification and identification of an angiotensin I-converting enzyme inhibitor from soy sauce. Biosci Biotechnol Biochem 1993; 57: 1107-1110.

16. Howes $L G$, Howes J B, Knight D C. Isoflavone therapy for menopausal flushes: a systematic review and meta-analysis. Maturitas 2006; 55: 203-211.

17. Sandberg AS. Bioavailability of minerals in legumes. Br J Nutr 2002; 88(Suppl 3): S281-S285.

18. Hurrell R F. Influence of vegetable protein sources on trace element and mineral bioavailability. J Nutr 2003; 113(Suppl 9): 2973S-2977S.
19. Husain Z, Schwartz R A. Food allergy update: more than a peanut of a problem. Int J Dermatol 2013; 52: 286-294.

20. Sampson H A. Update on food allergy. J Allergy Clin Immunol 2004; 113: 805-819.

21. Danchaivijitr A, Nakornchai S, Thaweeboon B et al. The effect of different milk formulas on dental plaque $\mathrm{pH}$. Int J Paediatr Dent 2006; 16: 192-198.

22. Sheikh $\mathrm{C}$. Evaluation of plaque $\mathrm{pH}$ changes following oral rinse with eight infant formulas. Paediatr Dent 1996; 18: 200-204.

23. Bhat S S, Dubey A. Acidogenic potential of soya infant formula in comparison with regular infant formula and bovine milk: a plaque $\mathrm{pH}$ study. J Indian Soc Paedod Prev Dent 2003; 21: 30-34.

24. Dashper S G, Saion B N, Stacey M A et al. Acidogenic potential of soy and bovine milk beverages. J Dent 2012: 40: 736-741.

25. Zohoori FV, Moynihan P J, Omid N, Abuhaloob L, Maguire A. Impact of water fluoride concentration on the fluoride content of infant foods and drinks requiring preparation with liquids before feeding. Community Dent Oral Epidemio/ 2012; 40: 432-440.

26. Van Winkle $S$, Levy S M, Kiritsy M C, Heilman J R, Wefel J S, Marshall T. Water and formula fluoride concentrations: significance for infants fed formula. Paediatr Dent 1995; 17: 305-310.

27. Clifford $H$, Olszowy $H$, Young $M$, Hegarty J, Cross M. Fluoride content of powdered infant formula meets Australian food safety standards. Aust N Z J Public Health 2009; 33: 573-576.

28. Liu C. Wyborny LE, Chan J T. Fluoride content of dairy milk from supermarket a possible contributing factor to dental fluorosis. Fluoride 1995; 28: 10-16.

29. Marthaler T M. Changes in dental caries 1953-2003. Caries Res 2004; 38: 173-181.

30. von der Fehr F R, Haugejorden 0. The start of caries decline and related fluoride use in Norway. Eur J Oral Sci 1997; 105: 21-26.

31. Tubert-Jeannin $S_{1}$ Auclair $C_{1}$ Amsallem E et al. Fluoride supplements (tablets, drops, lozenges or chewing gums) for preventing dental caries in children. Cochrane Database Syst Rev 2011; 12: CD007592.

32. Browne $D$, Whelton $H, O^{\prime}$ Mullane D. Fluoride metabolism and fluorosis. J Dent 2005; 33: 177-186.

33. Hong L, Levy S M, Warren J J, Broffitt B, Cavanaugh J. Fluoride intake levels in relation to fluorosis development in permanent maxillary central incisors and first molars. Caries Res 2006; 40: 494-500.

34. Martínez-Mier E A, Cury J A, Heilman J R et al. Development of gold standard ion-selective electrode-based methods for fluoride analysis. Caries Res 2011; 45: 3-12.

35. Pagliari A V, Moimaz S A, Saliba O, Delbem A C, Sassaki $\mathrm{K}$ T. Analysis of fluoride concentration in mother's milk substitutes. Braz Oral Res 2006; 20: 269-274.

36. Buzalaf M A, de Almeida B S, da Silva Cardoso V E, Olympio K P, de Almeida Furlani T. Total and acidsoluble fluoride content of infant cereals, beverages and biscuits from Brazil. Food Addit Contam 2004; 21: 210-215.

37. McLaughlin M J, Tiller K G, Naidu R, Stevens D P. Review: the behaviour and environmental impact of contaminants in fertilizers. Aust J Soil Res 1996; 34: $1-54$.

38. McBride M B, Richards B K, Steenhuis T, Spiers $G$. Molybdenum uptake by forage crops grown on sewage sludge-amended soils in the field and greenhouse. J Environ Qual 2000; 29: 848-854.

39. Buzalaf M A, Pessan J P, Fukushima R, Dias A, Rosa $H$. Fluoride content of UHT milks commercially available in Bauru, Brazil. J Appl Oral Sci 2006; 14: 38-42.

40. Dabeka R W, McKenzie A D. Lead, cadmium, and fluoride levels in market milk and infant formulas in Canada. J Assoc Off Anal Chem 1987; 70: 754-757.

41. Bánóczy J, Petersen P E, Rugg-Gunn A J. Milk fluoridation for the prevention of dental caries. Geneva: World Health Organization, 2009. 